\title{
norden
}

Nordic Council of Ministers

Ved Stranden 18

DK-1061 Copenhagen K

www.norden.org

NORDISKE ARBEJDSPAPIRER

NORDIC WORKING PAPERS

\section{Market surveillance of energy related PR}

Final report of the Nordic cooperation in 2012 due to ecodesign and energy labelling with focus on barriers

The Nordic Project Group 2012

(Project managers Anna Johansson and Lovisa Blomqvist)

NA2013:931

http://dx.doi.org/10.6027/NA2013-931 



\section{norden}

Nordic Council of Ministers

\section{Market surveillance of energy related products due to ecodesign and energy labelling}

Final report of the Nordic cooperation in 2012 with focus on barriers

Swedish Energy Agency

\section{EN ERGY}

Norwegian

Water Resources and Energy Directorate
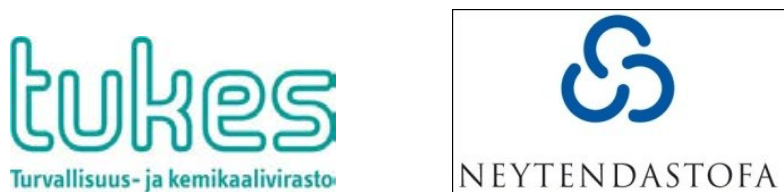


\section{Disclaimer}

\section{English}

This publication has been published with financial support by the Nordic Council of Ministers. The contents of this publication do not necessarily reflect the views, policies or recommendations of the Nordic Council of Minis-ters.

\section{Danish}

Denne rapport er udgivet med finansiel støtte fra Nordisk Ministerråd. Ind-holdet $i$ rapporten afspejler dog ikke nødvendigvis Nordisk Ministerråds synspunkter, meninger, holdninger eller anbefalinger.

\section{Swedish}

Denna rapport är utgiven av med finansiellt stöd från Nordiska ministerrådet. Innehållet i rapporten avspeglar inte nödvändigtvis Nordiska ministerrådets synpunkter, åsikter eller rekommendationer.

\section{Norwegian}

Denne rapporten er gitt ut med finansiell støtte fra Nordisk ministerråd. Innholdet i rapporten avspeiler imidlertid ikke nødvendigvis Nordisk ministerråds synspunkter, holdninger eller anbefalinger.

\section{Icelandic}

Norræna ráðherranefndin styrkti útgáfu skýrslunnar. Efni skýrslunnar endurspeglar pó ekki endilega sjónarmið, stefnu eða meðmæli Norrænu ráðherranefndarinnar.

\section{Finish}

Pohjoismaiden ministerineuvosto on myöntänyt tukea raportin julkaisemiseen. Raportin sisältö ei välttämättä edusta Pohjoismaiden ministerineuvoston kantaa, näkemyksiä tai suosituksia. 


\section{Preface}

This project report presents the work in 2012 within the Nordic cooperation on market surveillance of the regulations under the Ecodesign Directive and the Energy Labelling Directive. The Nordic cooperation started in an organized form in 2011 and has so far been very helpful and interesting for the project members.

We would like to thank the Nordic Council of Ministers for financing the build-up of the Nordic cooperation on market surveillance of ecodesign and energy labelling. A special thanks to Peter Molander at AGEE who has been involved and supported the project.

We also thank the Nordic countries that have actively participated and contributed to the project.

The Nordic Project Group, December 2012 


\section{Contents}

1 Summary 6

2 Background $\quad 7$

3 Introduction 9

4 Project organization 10

$5 \quad$ The Barrier project 11

6 Meetings during $2012 \quad 12$

6.1 Project meeting, Reykjavik, $27^{\text {th }}$ January ......................................... 12

6.2 Project meeting, Oslo, 17-18 ${ }^{\text {th }}$ April.................................................... 12

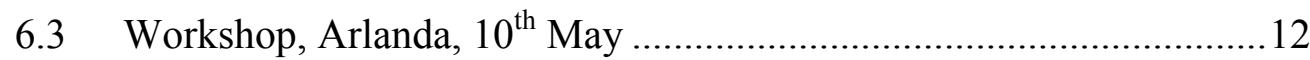

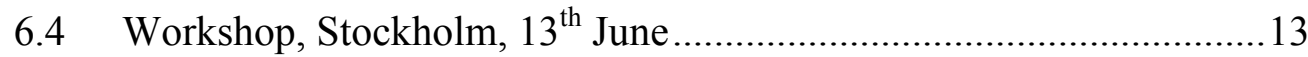

6.5 Baltic meeting, Riga, $31^{\text {st }}$ October....................................................13

6.6 Project meeting, Stockholm, 16-17 ${ }^{\text {th }}$ October ...................................14

6.7 Workshop, Helsinki, $17^{\text {th }}$ December..................................................14

6.8 Project meeting, Tampere, February 2013 ......................................14

7 Market surveillance exchange 15

7.1 Markets surveillance 2012 - results and activities ...........................15

7.2 Shared test results and document control 2012 ................................17

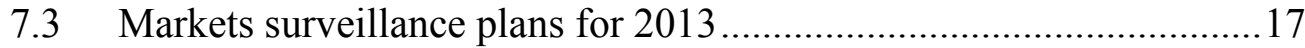

8 Questions to ADCO 18

$9 \quad$ Nordic Project 2013-2015 19

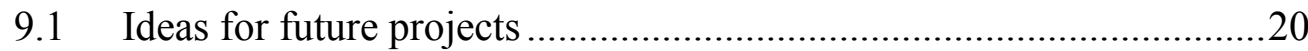

10 Evaluation and conclusions 21

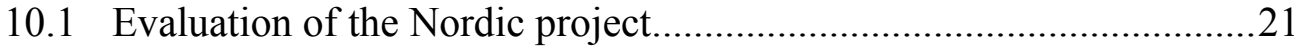

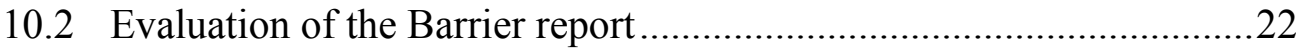

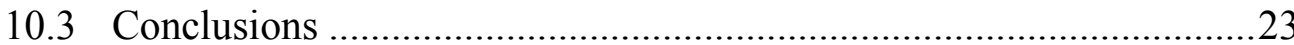

Appendix I: The Barrier Report 


\section{Summary}

In order to decrease the climate change, the European Union (EU) has established a goal to decrease the energy use with $20 \%$ in year 2020. The regulations under the Ecodesign and Energy Labelling Directives are important tools to reach this.

In order to be effective the directives and regulations are dependent on good market surveillance. As more products gets ecodesign and energy labelling regulations the market surveillance is getting more complicated and expensive. Cooperation between countries is necessary to be able to keep up good market surveillance on a wide range of products. The Nordic countries have much to win by cooperating at an early stage, as it increases the Nordic fellowship and competitiveness of the Nordic countries.

This is the second project report from the Nordic cooperation on market surveillance of ecodesign and energy labelling. The project has been financed by the Nordic Working Group on Energy Efficiency, AGEE, under the Nordic Council of Ministers. The Swedish Energy Agency has been the project manager. The project has its own steering committee with participants from the control authorities in Norway, Denmark, Finland, Iceland and Sweden.

In year 2012 the focus has been on barriers to cooperation. The Nordic project has, in 2012, included exchange of market surveillance plans and test results, three project meetings, one meeting with the Baltic countries, participation in AGEE workshops, two common papers with questions to ADCO and a lively discussion on barriers resulting in a focus report on barriers. The secretariat has sent monthly reports to the project group. Moreover, a project proposal for a continued Nordic cooperation in 2013-2015 has been written and sent to AGEE.

The barriers identified by the project group are: 1 Transposition of legislation different implementations in different countries, 2 Publication of test results, 3 Sanctions, 4 Test Laboratories, 5 Market surveillance and financial differences, 6 Buy or borrow products for test, 7 Who pays for the test, 8 Budget Procedures, 9 Language, 10 Commercial codes, 11 Use of databases. To ease the cooperation these barriers needs to be dealt with by the member states and in some cases by the European Commission. In the barrier report the Nordic project group presents suggestions on how to handle the identified barriers.

The Nordic cooperation within this project turned out to be very useful. The project group has been an important platform to discuss common questions and solutions and hopes to continue this kind of cooperation on market surveillance. With good cooperation, countries can benefit from each other's surveillance tests and together cover more products and models. This provides conditions for an effective supervision which provides a fair playing field, technological development and increased competitiveness. A Nordic cooperation in the field increases the Nordic solidarity and the Nordic countries competitiveness. 


\section{Background}

In order to decrease the climate change, the European Union (EU) has established a goal to decrease the energy use with $20 \%$ in year 2020. This is a goal not easy to reach and many different tools need to be used to really make a difference. The European Commission (COM) has calculated that the regulations under the Ecodesign and Energy Labelling Directives can decrease the energy use with 5\% in 2020 .

Ecodesign and energy labelling requirements can save large amounts of energy and are therefore important for climate action, improvements in non-toxic environment, acidification, etc. Today there are sixteen (16) ecodesign regulations decided so far. The ecodesign and energy labelling regulations are expected to yield a saving of 415 TWh in 2020 to EU level, compared to if no action had been taken. Market surveillance is necessary as if the products do not comply with current requirements, it has been estimated that $10 \%$ of energy savings are lost per year.

In 1992 the first Energy Labelling Directive (1992/75/EG) was established. Evidently this has really pushed products like washing machines and refrigerators to be much more energy efficient. The Energy labelling Directive was revised in $2010(2010 / 30 / \mathrm{EU})$. The scope was extended to all energy related products and the label is now international with symbols. Another important difference is that the Directive is followed by product specific EU regulations which, when published in The Official Journal of the European Union, are directly valid in all EU member states and already translated in all European languages. The labelling regulations require the manufacturers and retailers to put an energy label on the product, pointing out the energy consumption and other relevant information, which make it possible for the buyers to compare the products.

In 2005 (2005/32/EG) the Ecodesign Directive was established by the European Commission. It was revised in $2009(2009 / 125 / \mathrm{EU})$ and the scoop was extended from energy using products (EuP) to energy related products (ErP). The Directive only sets a frame; the rules are set out in product specific regulations, which are directly valid in all member states. The Ecodesign Directive and the regulations following set actual limits on how much energy and other resources a product is allowed to use to be put on the European market. This means that if a product does not meet the ecodesign requirements it is illegal to put on the market.

In order to be effective, the EU directives and regulations are dependent on good market surveillance. As more and more products get ecodesign and energy labelling regulations the market surveillance is getting more complicated and expensive. Cooperation between countries is necessary to be able to keep up good market surveillance on a wide range of products. 
The Nordic countries have much to win by cooperating at an early stage and this project was initiated in order to start Nordic cooperation on market surveillance of ecodesign and energy labelling. Nordic cooperation increases the Nordic solidarity and competitiveness of the Nordic countries.

This is the second project report from the Nordic cooperation on market surveillance of ecodesign and energy labelling. In 2011 the main focus was on how to perform market surveillance tests together and this year, 2012, the main project focus has been to identify and reduce barriers for cooperation.

In 2011 the work began to build a close cooperation on the supervision of ecodesign and energy labelling to retain a system for coordination and communication of market surveillance plans, test results and experiences from market surveillance in the Nordic countries. This work continued in 2012 to smoothen the continuing knowledge exchange.

In 2011, the Nordic project "Nordic Testing of Energy Products" completed two market surveillance tests, by testing 11 refrigerators and 11 ballasts, to verify whether they comply with ecodesign and energy labelling requirements. Four products (two refrigerators and two ballasts) did not meet the requirements. The total saving potential of these two refrigerators is $221000 \mathrm{kWh}$ (if they had met the requirements). The test showed that none of theelectromagnetic ballasts did comply with the declared value. The manufacturers were notified of the results and decided to relabel the products.

The project has been financed by the Nordic Working Group on Energy Efficiency, AGEE, under the Nordic Council of Ministers. The Swedish Energy Agency has been the project manager. The project has its own steering committee with participants from the Market surveillance authorities in Norway, Denmark, Finland, Iceland and Sweden.

It is not easy to develop and maintain high level of market surveillance due to the large variety of products and aspects such as (energy, presence of hazardous substances, information, etc.). It is impossible to test all models of all the products in each country. With good cooperation, countries can benefit from each other's surveillance tests, and as a result of that cover more products and models. The Nordic countries will benefit from being early in this work. In many cases there are already similar requirements in countries outside the $\mathrm{EU}$, and it is therefore very important to improve the competitiveness of Nordic companies through new requirements and related supervision.

Well-functioning market surveillance drives the companies and importers to develop better products. A company which quickly adapts to new requirements will have an increased competitiveness in the international market. Many companies point out that good enforcement provide a fair playing field and fair competition, which is necessary for technological development. 


\section{Introduction}

The Nordic project aims to develop the Nordic cooperation on market surveillance of ecodesign and energy labelling requirements. To reach this the project aims to build a close cooperation on the supervision of ecodesign and energy labelling with the expected result of a system to coordinate and communicate to each other surveillance plans, test results and experiences from each Market surveillance authority of the Nordic countries. The main focus in 2012 has been to identify and reduce barriers for cooperation.

The Nordic countries aim to be the predecessor in the EU and in the longer term to assist other countries with their tests and control activities. The expectation in the extension is that this type of project leads to more effective market surveillance as more products and models are tested and the exchange of knowledge between countries occur. This in turn contributes to the development of energy efficient products that deliver increased competitiveness and reduced energy use.

There are however not always easy to cooperate and the project has identified a couple of barriers for the cooperation. In the barrier report the barriers are discussed and suggestions on how to overcome the barriers are given. For example each time a new directive is established or revised all member states need to implement them into national law and in this work there will be different interpretations. What this can lead to and how to overcome this is discussed in the legislation chapter of the barrier report.

In 2012 the Nordic project has included:

- the Barrier project

- monthly reports

- exchange of market surveillance plans

- exchange of test results and document control results

- three project meetings

- one meeting with the Baltic countries

- participation in workshops with the AGEE

- two common papers with questions to ADCO

In addition, a project proposal for a continued Nordic cooperation in 2013-2015 has been written and sent to AGEE.

This project report presents the work achieved within the project in 2012, with the Barrier report as an appendix. 


\section{$4 \quad$ Project organization}

The project is funded by the Nordic council of Ministers which is therefore the project owner through Peter Molander, Working Group for Energy Efficiency (AGEE).

The project has its own steering/reference group with participants from Market Surveillance Authorities in Norway, Denmark, Finland, Iceland and Sweden. The Swedish Energy Agency is the project manager.

The project group (eg. members of the project) are:

Sweden; Energimyndigheten/Swedish Energy Agency; Anna Johansson (project manager), Lovisa Blomqvist (project manager Nov-Dec), Nils Ahlén (project manager Barrier report), Stefan Nording, Emma Hagman Rang, Karolina Petersson, Kristina Wikström

Denmark; Energistyrelsen/Danish Energy Agency/DEA; Peter Nielsen, Charlotta Castenfors Laursen

Finland; Tukes/Finnish Safety and Chemicals Agency; Teemu Hartikainen, Marika Keskinen

Iceland; Forbrugerstyrelsen; Tryggvi Axelsson, Guðrún Lárusdóttir, Egill Gylfaso

Norway; Norges vassdrags- og energidirektorat/Norwegian Water Resources and Energy Directorate/NVE; Knut N. Knutsen, Einar Tommelstad, Kirsti Hind Fagerlund, Lasse Vannebo

In 2012 the Nordic project was divided in two subprojects:

A) Secretariat and coordination of the project

B) Barrier project

Anna Johansson, Swedish Energy Agency, has been the project manager for the entire project as well for the subproject A. In November 2012 Anna was replaced as project manager by Lovisa Blomqvist, Swedish Energy Agency. Subproject A includes exchange of market surveillance plans, organization of workshops, project meetings, coordination of common questions to ADCO etc.

Nils Ahlén, Swedish Energy Agency, has been the project manager of subproject $\mathrm{B}$ which has included identification and discussion on barriers for cooperation on market surveillance and the writing of a report on barriers. 


\section{$5 \quad$ The Barrier project}

In 2012 one of the main tasks of the Nordic cooperation on market surveillance of ecodesign and energy labelling has been to define and investigate barriers for cooperation. This work resulted in a Barrier report.

A barrier can be defined as something that hinders the effectiveness of supervision in any of the countries or makes cooperation between countries difficult.

The barriers identified are: 1) Transposition of legislation - different implementations in different countries, 2) Publication of test results, 3) Sanctions, 4) Test Laboratories, 5) How much market surveillance and financial differs, 6) Buy or borrow products for test, 7) Who pays for the test, 8) Budget Procedures, 9) Language, 10) Commercial codes, and 11) Use of databases.

The Barrier report presents proposals on how to deal with the identified barriers. Some barriers require changes in national or EU legislation, others can be eased through changes in work methods while some may be impossible to solve. The list of barriers identified is not exhaustive and is likely to increase with time.

It is important to continue to work with the barriers in the Nordic countries, but also in the work with the Commission and with other countries. It is of great importance for the Nordic cooperation that each Nordic country tries to embody the recommendations from the Barrier report on how to deal with the barriers. The Nordic countries should also address the Commission the appropriate recommendations from this report. It is especially important to keep the solutions to the barriers identified in mind during the work with revising the Ecodesign and Energy Labelling Directives in 2014 and in the subsequent work with revising the national legislation.

Read the full Barrier report in Appendix I. 


\section{$6 \quad$ Meetings during 2012}

\subsection{Project meeting, Reykjavik, $27^{\text {th }}$ January}

The Nordic project of 2012 was initiated at the Nordic project meeting in Iceland at Forbrugerstyrelsen, Borgartún 21, Reykjavik 27th January 2012.

Participants were: Guðrún Lárusdóttir, Iceland (host); Tryggvi Axelsson, Iceland (host); Peter Nielsen, Denmark; Charlotta Castenfors Laursen, Denmark; Knut N. Knutsen, Norway; Einar Tommelstad, Norway; Fagerlund Kirsti Hind, Norway; Marika Keskinen, Finland; Anna Johansson, Sweden (Chair); Nils Ahlén, Sweden (secr); Peter Molander, (secr) Nordic Working Group for Energy Efficiency.

The meeting in Reykjavik finalized the Nordic project of 2011 and started up the Nordic project of 2012. For details on the Nordic project of 2011 see Final report Nordic Testing of Energy Products 2011.

\subsection{Project meeting, Oslo, 17-18 ${ }^{\text {th }}$ April}

On the $18^{\text {th }}$ of April 2012 a project meeting was held in Oslo, NVE, Middelthunsgate 29. The sub project on Barriers to cooperation was then started. It was also decided to share market surveillance plans in the form of an excel spread sheet. The ADCO-meeting 11-12 April in Teddington, United Kingdom, was discussed and summarized in this meeting. Some matters of the 2011 Nordic Project were also discussed. Karolina presented the EU-project Ecoplient, another project focusing on cooperation in market surveillance of ecodesign and energy labelling. Market surveillance plans for each country were presented.

Participants: Knut N. Knutsen, Norway (host); Fagerlund Kirsti Hind, Norway (host); Lasse Vannebo, Norway (host); Guðrún Lárusdóttir, Iceland; Tryggvi Axelsson, Iceland; Peter Nielsen, Denmark; Charlotta Castenfors Laursen, Denmark; Marika Keskinen, Finland; Anna Johansson, Sweden (Chair); Nils Ahlén, Sweden (secr); Stefan Nording, Sweden; Karolina Petersson, Sweden (partly); Peter Molander, (secr) Nordic Working Group for Energy Efficiency.

\subsection{Workshop, Arlanda, $10^{\text {th }}$ May}

In 2012 AGEE (the Working Group for Energy Efficiency under the Nordic Council of Ministers) financed two Nordic projects; the current "Market surveillance of energy related products" and "A Nordic view on EU Energy Efficiency targets".

On the $10^{\text {th }}$ May 2012 the project managers of the project "A Nordic view on EU Energy Efficiency targets" arranged a workshop in Stockholm. All members of the reference group of the project "Market surveillance of energy related products" were invited to participate in the workshop and Anna Johansson 
(project manager), Anna Carlén (head of Department, Swedish Energy Agency) and Guðrún Lárusdóttir (Iceland) participated.

\subsection{Workshop, Stockholm, $13^{\text {th }}$ June}

The AGEE group had a meeting $13^{\text {th }}$ June 2012 and in connection to the meeting, we arranged a mini workshop. Participants from our project were Anna Johansson, Nils Ahlén and Peter Nielsen. A presentation of the halfway report was done. The project members of "A Nordic view on EU Energy Efficiency targets" also participated in this miniworkshop.

\subsection{Baltic meeting, Riga, $31^{\text {st }}$ October}

The Baltic countries have shown a great interest in the Nordic cooperation on market surveillance. The Baltic countries are members of the European Union since 2004 and are therefore subjects to the Ecodesign and Energy labelling Directives. However the Baltic countries all have very small budgets to work with the directives and product regulations. Therefore, cooperation with for example the Nordic countries would be of great importance for the market surveillance to be efficient.

In order to investigate possible cooperation, Nils Ahlén and Emma Hagman Rang, as representatives for the Nordic project, met with representatives from Latvia and Estonia in Riga $31^{\text {st }}$ October 2012.

Participants of the meeting were: Nils Ahlén (Swedish Energy Agency), Emma Hagman Rang (Swedish Energy Agency), Svetlana Mjakuskina (Consumer Rights Protection Centre), Linda Rinkule (Consumer Rights Protection Centre), Meelis Kärt (Estonian Technical Surveillance Authority), Janne Kurg (Estonian Technical Surveillance Authority), Anna Fandula, (Technical and Metrological Surveillance Division, Consumer Rights Protection Centre), Reinis Berzins, (Internal Market Department, Ministry of Economics of the Republic of Latvia).

Estonia performs some of its market surveillance by checking energy labelling in stores. The Estonian Technical Surveillance Authority mostly co-operate with other Estonian supervision institutions.

In Latvia there are around 26 persons working with ecodesign and energy labelling. The responsible Department have close cooperation with the Latvian Custom and a lot of non-compliant lamps have been found and stopped at the customs. The Latvian Department added at the meeting that they are very interested in information on tested products within the Nordic Countries.

Latvia is very interested in becoming a part in the Nordic Project but they do not know how to contribute as none of the Baltic Countries have the economy for performing tests at the moment.

The conclusion from this meeting is that the Nordic project should consider including the Baltic countries in the continued cooperation as there is much to win 
on having the same rules and an efficient common market surveillance concerning ecodesign and energy labelling.

\subsection{Project meeting, Stockholm, $16-17^{\text {th }}$ October}

There was a project meeting held in Stockholm 16-17 $7^{\text {th }}$ October 2012.

Participants were: Peter Nielsen, Denmark; Charlotta Castenfors Laursen, Denmark; Einar Tommelstad, Norway; Lasse Vannebo, Norway; Guðrún Lárusdóttir, Iceland; Egill Gylfaso, Iceland; Anna Johansson, Sweden (chair); Emma Hagman Rang, Sweden; Nils Ahlén, Sweden; Stefan Nording, Sweden; Karolina Petersson (partly).

In the first meeting day presentations and discussions about market surveillance in 2012 and the plans for 2013 were held. For details see chapter 8 on market surveillance in this report. Also some suggestions for activities in 2013 were discussed, for details see chapter 10 of this report.

The second day, $17^{\text {th }}$ October, the focus was on barriers. The barriers identified were discussed and developed. For details, see the Barrier report.

\subsection{Workshop, Helsinki, $17^{\text {th }}$ December}

AGEE had a meeting in Helsinki $17^{\text {th }}$ December 2012 and invited the two AGEE projects to present the final reports for 2012. Lovisa Blomqvist, Nils Ahlén and Emma Hagman Rang participated and presented the Barrier report and the final report of this Nordic project. AGEE concluded that the project was finalised. The final report is to be sent to AGEE latest January 2013.

\subsection{Project meeting, Tampere, February 2013}

The next project meeting is planned to be held at Tukes in Tampere, Finland, in February 2013. 


\section{$7 \quad$ Market surveillance exchange}

National market surveillance plans have been exchanged within this project. The project group has decided that preliminary market surveillance plans should be sent to all project members in November each year, covering the following year. An excel spread sheet, distributed by Sweden, should be used as a template. This should be followed up by an updated market surveillance plan sent to all project members in February the current year.

In 2012 the exchange of market surveillance plans has been better than the year before, however it could still be improved.

According to the European Commission, market surveillance plans should be reported to Circa database in November, so Nordic practice is well coordinated with this.

\subsection{Markets surveillance 2012 - results and activities}

Denmark: has, due to a delayed budget, not been able to test as much as wanted. $15-20$ pcs. of fridge/Freezers (combi top) with one compressor.

20 pcs. of electrical motors

10 pcs. of dishwashers

Planning to test CFL regarding to $\mathrm{lm} / \mathrm{W}$ ratio before the end of 2012 .

All of the tested products can be found on http://www.ens.dk

The Danish Energy Agency plans to launch a new design of their website

Norway: A consultant has been procured to perform market surveillance on behalf of NVE.

A test has been performed of 11 CFLs. NVE has notified the project group of the test results.

Store check; Checking energy labelling of most types of household appliances in 60 stores.

NVE has not been able to perform as much market surveillance as wanted, due to budget discussions within the Norwegian government.

Finland: Will be launching a new webpage (beginning of December) similar with ens.dk in Denmark.

5 TVs were tested (Samsung LE32E425E2W, Sharp LC-32SHI30E, Grundig 26

VLC4102 T2, Division DTV24047D, Finlux 32FLYR930HU). They were all 
found compliant with regulation 642/2009, only exception being Samsungs lessthan-allowed luminance value at factory settings.

478 stores were visited for energy labeling check, where in total 22229 products were checked for label. In 7152 cases the label was not visible, and corrective action was taken.

45 manufacturers were visited for communications purposes concerning new and upcoming Ecodesign regulations.

Iceland: The Ecodesign Directive and Labelling Directives are not yet implemented in Icelandic national law. They plan to perform an information campaign, which is not yet decided. No tests have been performed due to their small budget.

Sweden: has perfomed market surveillance of:

4 washing machines (ongoing)

5 fridge/freezers (SidebySide) (almost ready)

20 CFL (almost ready)

5 TVs (LED, LCD, Plasma). One of the selected brands is based on the test that Denmark performed (almost ready)

10 External power supplies (almost ready)

Documentary check of 21 suppliers of electrical motors (ongoing)

Market surveillance on internet, advertising leaflets (ongoing)

Store check; checking of the energy labelling in stores for fridges, freezers, dishwashers, washing machines, tumble dryers, wine coolers, TVs (almost ready)

Sweden has developed a lightning app (Lampguiden) that is available for both Android and iOS. Hopefully, this app can be shared with the Nordic countries soon.

A test (not for market surveillance) of 10 brands of geothermal heatpumps has been performed and was published in December 2012 on the Swedish Energy Agency's website. The test covers nearly the whole market of heat pumps. Some of the models are sold on the Nordic market.

The project had still 49000 DKK to spend at the project meeting in October 2012. The group discussed if an additional test of ballasts should be perfomed, but the members agreed no additional tests will be carried out, due to lack of time and the difficulties to find common models on the Nordic market. 


\subsection{Shared test results and document control 2012}

Since the beginning of this Nordic cooperation it has been discussed how test results should be shared. Also information on document control should be shared. Information is currently being shared, however still not in a very organized form. For example the ongoing dialogue on interpretation of the ecodesign and energy labelling legislation has been very helpful.

Denmark shared results regarding TVs in the beginning of 2012 and Sweden decided to select and test one of the brands which did not comply in the Danish test.

Norway shared test results of CFLs during October 2012 to the Nordic countries and Sweden will follow up if any of these models are to be found on the Swedish market.

Sweden has a number of surveillance tests almost ready (see chapter 8.1) and the results will be shared as soon as possible.

Sweden shared a test, not for market surveillance, of geothermal heat pumps in October 2012.

Many of the market surveillance activities in the Nordic countries during the year of 2012 are still ongoing and will soon be finished. Hopefully all the participating countries will continue to share test results in the development of efficient Nordic market surveillance of ecodesign and energy labelling.

\subsection{Markets surveillance plans for 2013}

Sweden (Stefan Nording) sent out a designed excel sheet template where each country should fill in the market surveillance plan for 2013. Sweden will distribute the filled in sheet in the end of January 2013.

Denmark: The plan for 2013 will not be determined until January-February 2013. Denmark plans to test air conditioners, air-to-air heat pumps and to continue to test electrical motors.

Denmark suggests for all of the Nordic countries to perform a common information campaign. Another idea is for the Nordic countries to perform a joint surveillance test of air-to-air heat pumps during 2013.

Norway: Will most likely have a smaller budget for 2013, which will affect the surveillance activities for that year. A preliminary plan was sent to the Nordic countries in November 2012. The final plan will be set in January 2013.

Finland: Have sent a preliminary plan for 2013 in December 2012.

Iceland: Will most likely perform technical documentary check in 2013.

Sweden: Has adopted a market surveillance plan for 2013, which was sent to the Nordic colleagues in the middle of December 2012. 


\section{Questions to ADCO}

An important outcome of the Nordic cooperation in 2012 is that we have discussed and coordinated questions that we sent to ADCO twice during 2012.

ADCO is the Administrative Cooperation between market surveillance authorities within EU and EEA for ecodesign and energy labelling. ADCO holds meetings twice a year to discuss issues due to the interpretation of the Ecodesign and Energy labelling Directives and product regulations.

The first ADCO meeting in 2012 was held 11-12 April in Teddington, United Kingdom. There were 14 countries represented and Villo Lelkes represented the European Commission. For the first time the Nordic countries submitted compiled common questions to an ADCO meeting. These and other questions were discussed and answered by email and some were discussed at the meeting.

A second ADCO meeting was held $22^{\text {nd }}$ November 2012 in Haag, Netherlands. Within the Nordic project, a continued discussion has been held on difficulties and grey areas. The Nordic countries put together a list of questions which were sent to ADCO before the meeting $22^{\text {nd }}$ November. These questions were, together with other asked questions, answered by the Commission by email before the meeting and some were discussed at the meeting. The written answers will be discussed at the next Nordic meeting.

It has turned out to be useful for the Nordic countries to discuss the questions as some may be solved already in the discussion phase. We also helped each other to understand the answers from the Commission. Furthermore, we think it has been helpful for the Commission to get one well-coordinated sheet of questions from the Nordic countries instead of one from each country. 


\section{$9 \quad$ Nordic Project 2013-2015}

A project proposal for a continued Nordic Project has been sent to the secretariat of the Nordic Council of Ministers. The Nordic energy ministers met in Trondheim, Norway, $11^{\text {th }}$ October 2012. They decided to support a continued Nordic cooperation on market surveillance of ecodesign and energy labelling on a more permanent basis for three years. The project will be financed by the Nordic Council of Ministers and the practical follow-up will be done by the secretariat of the Nordic Council of Ministers. As the proposed project has a large budget, there will be an international call for this project. The details for the running of the Nordic Project in 2013-2015 will be set as it is decided who will be running the project.

The cooperation 2011-2012 between the Market Surveillance Authorities in the Nordic Countries has been successful. The Swedish Energy Agency has been the project manager and has together with a reference group with participants from the authorities in all Nordic countries, reported to the Nordic Group for Energy Efficiency, AGEE. The project has demonstrated the differences in the extent of market control of energy related products in the five participating countries. The collaboration has shown that all countries have the advantages of a Nordic integration and can achieve significant benefits from closer cooperation.

The project has also shown that one can achieve benefits and "Nordic synergy" with a loose integration between national market surveillance operations, which are informal and generally based on personal relationships. This work can also be used as input to various on-going European projects.

There is a need of continued cooperation for 2013-2015. Marked surveillance of the Ecodesign and Energy Labelling directives involve complex issues of both legal and technical nature. The complexities in the area also increase with time and more products are regulated as, for example, business-to-business and on-line sales are included. Market surveillance within each country is therefore in a constant process of change where new structures and working methods must be developed.

The project from 2011-2012 has also shown that none of the participants from national authorities have a free capacity to allocate funding to Nordic cooperation in this field and secretariat assistance for management and coordination of cooperation provides significant potential for cooperation.

The Nordic cooperation could continue with regards to reporting, funding and organisation as follows: Cooperation takes place over three years under a programme with fixed programme funding, a Nordic manager and leader, a peer group and a continuing cooperation with different activities and projects. 


\subsection{Ideas for future projects}

Below are some suggestions for future common activities that have been raised by the project members during 2012:

A suggestion is to set up a workshop together with the other NMR-project "Ecodesign and Future Product Policy", to discuss the results of both groups. On the project meeting $17^{\text {th }}$ October 2012, Karolina Petersson informed the project group about this Nordic project which is focusing on the environmental aspects in relation to the Ecodesign directive.

A suggestion for a common activity in 2013 could be that the group participates at the ECEEE in France in the beginning of June. Unfortunately the time has run out to send in both papers and posters. However, there is still the possibility to arrange an informal session.

Denmark suggests for all of the Nordic countries to perform a common information campaign.

And another idea from Denmark is for the Nordic countries to perform a joint surveillance test of air-to-air heat pumps during 2013.

A suggestion from Sweden is to produce a paper on how to evaluate market surveillance in stores. 


\section{Evaluation and conclusions}

\subsection{Evaluation of the Nordic project}

The project has been a success so far, even though there is still much work to be done within the Nordic cooperation. The group has found it helpful with the secretariat responsible for arranging meetings, sending out monthly reports and managing the project. The exchange of market surveillance plans is now more organized and better working even if there is still a potential for development. The project meetings have been successful with almost all countries represented each time. The discussions have been engaged and interesting.

Linguistically, the project's steering committee decided that mail correspondence to all project members should be in English in order to facilitate the work, which has worked well.

The Nordic countries have found it helpful to cooperate with questions to the ADCO-meetings. Some questions may be solved already in the discussion. We also helped each other to understand the answers from the Commission.

Furthermore we think it has been helpful for the Commission to get one wellcoordinated sheet of questions from the Nordic countries instead of one from each country. It is an advantage with a common Nordic voice when discussing with the Commission.

A positive effect from the project is that the participants have started to cooperate beyond this project, for example by exchanging unofficial questions about interpretation of legislation, differences in the national implementations of the directives, practical work with the market surveillance, problematic products and producers etc. The project has helped creating a well-functioning network which is of great help in the daily work in all the countries.

There may be an extension of the Ecodesign Directive to non-energy related products in the future. This implies new challenges for market surveillance. Enhanced surveillance of aspects other than energy-related may also be required, such as toxic content, lifetime and information. Several EU projects related to the surveillance of ecodesign and energy labelling is also in progress and it is important that the Nordic countries are involved in the development of techniques, methodologies and practices.

With good cooperation, countries can benefit from each other's surveillance tests and document controls, and as a result of that, cover more products and models. This provides conditions for an effective supervision, which in turn generates a fair playing field, technological development and increased competitiveness. Therefore, cooperation on market surveillance between countries is necessary and important. A Nordic cooperation in this field increases the Nordic solidarity and the Nordic countries' competitiveness. 
Technical and practical problems that may occur can be solved optimally by member states. However, projects like this provide good conditions for obtaining a clear forum to meet, discuss and coordinate regulatory practices in the different authorities across the Nordic countries.

The project members agree that there is much to gain from a Nordic cooperation on market surveillance of ecodesign and energy labelling requirements, both financially, resource-wise and in the view of enhanced competitiveness and a common voice when discussing with the Commission.

The project has positive effects for the Nordic cooperation, for example:

- Refers to activities that would take place within a national framework, but with tangible benefits achieved through joint Nordic solutions.

- Manifests and develops the Nordic solidarity.

- Increases the Nordic competence and competitiveness.

- Gives concrete helpful results for continued cooperation on surveillance tests and document controls.

- Proposes how the cooperation can continue to be organized, managed and financed.

- Proposes how to improve technical, legal, linguistic and practical conditions for cooperation on surveillance testing etc across the national borders within the Nordic cooperation.

\subsection{Evaluation of the Barrier report}

This Nordic project aims to develop the Nordic cooperation on market surveillance of ecodesign and energy labelling. In 2012 the main focus of the Nordic project has been on barriers to cooperation.

Of the 13 barriers identified by the group only some have simple solutions. The work with barriers resulted in a list of actions on how to solve or work with the barriers. To ease the cooperation, each of the Nordic countries should try to address the recommendations addressed to the member states and also propose to the Commission necessary amendments in the directives or regulations.

It is especially important to keep all the recommendations in mind during the work with revising the Ecodesign and Energy Labelling Directives in 2014, and in the following work with revising the national legislation.

The work with barriers is definitely not finished by the Barrier report and as more complex product groups and aspects as resource efficiency are taken into the system, we will have even more complicated tasks to deal with. 


\subsection{Conclusions}

The Nordic project has been a success so far, even though there is much work still to be done within the Nordic cooperation. It has been of great importance to build a platform for cooperation and also to focus on certain tasks.

The focus on common tests during 2011 was a useful experience. The focus on barriers in 2012 has been a good way to concretize challenges and resulted in a Barrier report with a list of actions on how to solve or work with the barriers. To ease the cooperation these barriers need to be further evaluated and addressed by the Nordic countries and in some cases, by the European Commission.

The group has found it helpful with the secretariat responsible for deadlines, arranging meetings, sending out monthly reports and managing the project. The exchange of market surveillance plans and test results is now more organized and works better, even if there is still development potential. The project meetings have been successful with almost all countries represented each time and with engaged and interesting discussions. The Nordic countries have found it helpful and effective to work together with questions to ADCO. The project has helped creating a well-functioning network, which is of great help in the daily work in the Nordic countries.

There is much to gain from a Nordic cooperation on market surveillance of ecodesign and energy labelling requirements, both financially, resource-wise and in the view of enhanced Nordic competitiveness and as a common voice when discussing with the Commission. Therefore, we find that it is of great interest that this kind of Nordic cooperation continues and is further developed. 